
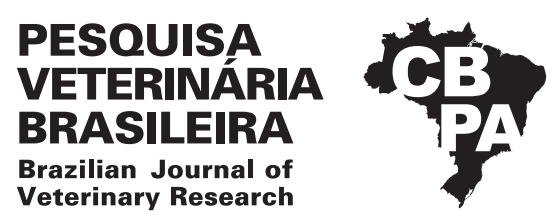

Pesq. Vet. Bras. 38(8):1615-1621, agosto 2018 DOI: $10.1590 / 1678-5150-P V B-5343$

Original Article

ISSN 0100-736X (Print)

ISSN 1678-5150 (Online)

\title{
Antigenic and immunogenic properties of the canine distemper virus nucleocapsid protein expressed in Escherichia coli employing codon optimized synthetic gene ${ }^{1}$
}

\author{
Maureen H.V. Fernandes², Paula F. Finger ${ }^{2}$, Rodrigo C. Cunha ${ }^{3}$, \\ Gilberto D’Avila Vargas ${ }^{4}$, Geferson Fischer ${ }^{4}$, Marcelo de Lima ${ }^{4}$ \\ and Silvia O. Hübner ${ }^{4 *}$
}

\begin{abstract}
Fernandes M.H.V., Finger P.F., Cunha R.C., Vargas G.D., Fischer G., Lima M. \& Hübner S.O. 2018. Antigenic and immunogenic properties of the canine distemper virus nucleocapsid protein expressed in Escherichia coli employing codon optimized synthetic gene. Pesquisa Veterinária Brasileira 38(8):1615-1621. Departamento de Veterinária Preventiva, Universidade Federal de Pelotas, Campus Capão do Leão, Avenida Eliseu Maciel s/n, Jardim América, Capão do Leão, RS 96900-010, Brazil. E-mail: sohubner@yahoo.com.br

Despite common occurrence and importance of canine distemper disease the majority of tests currently available for diagnosis are hampered by either low sensitivity or specificity. In this study it was evaluated antigenic and immunogenic characteristics of a conserved region of nucleocapsid protein of canine distemper virus (rCDV NP) expressed in Escherichia coli employing a codon optimized synthetic gene. The expression of rCDVNP in Star strain (mean $300 \mu \mathrm{g} / \mathrm{mL}$, purified) was confirmed by SDS-PAGE and Western blot analysis by using His-Tag monoclonal antibodies. Western blot and ELISA, employing positive and negative control dog sera, demonstrated the rCDVNP antigenicity. The rCDVNP was inoculated in hens and immunoglobulin Y ( $\operatorname{IgY})$ was purified from the egg yolk. The mean yield of IgY was $28.55 \mathrm{mg} / \mathrm{mL}$. IgY reacted with the recombinant protein as demonstrated by Western blot and ELISA assays. In summary, our findings demonstrated that rCDVNP is antigenic since CDV positive dog sera recognized the protein in vitro. Additionally, the rCDVNP proved to be immunogenic in hens being possible to isolate a high concentration of specific IgY antibodies from the egg yolk. Taken together, these results indicate that the rCDVNP along with the specific IgY could be useful tools for development of the canine distemper immunodiagnostic assays.
\end{abstract}

INDEX TERMS: Dogs, antigenic, immunogenic, canine distemper virus, nucleocapsid protein, Escherichia coli, codon, synthetic gene, expression, CDV, NP, IgY, viroses.

RESUMO.- [Propriedades antigênicas e imunogênicas da proteína do nucleocapsídeo do virus da cinomose canina expressa em Escherichia coli empregando gene sintético com codons otimizados.] Apesar da ocorrência comum e importância da cinomose canina, a maioria dos testes atualmente

\footnotetext{
${ }^{1}$ Received on June 6, 2017.

Accepted for publication on July 19, 2017.

${ }^{2}$ Programa de Pós-Graduação em Medicina Veterinária, Faculdade de Veterinária, Universidade Federal de Pelotas (UFPel), Campus Capão do Leão, Capão do Leão, RS 96900-010, Brazil.

${ }^{3}$ Centro de Desenvolvimento Tecnológico, Biotecnologia, Universidade Federal de Pelotas (UFPel), Campus Capão do Leão, Capão do Leão, RS 96900-010.

${ }^{4}$ Departamento de Veterinária Preventiva, Universidade Federal de Pelotas (UFPel), Campus Capão do Leão, Avenida Eliseu Maciel s/n, Capão do Leão, RS 96900-010. *Corresponding author: silviaohubner@gmail.com
}

disponíveis para diagnóstico são prejudicados pela baixa sensibilidade ou especificidade. Neste estudo foram avaliadas características antigênicas e imunogênicas de uma região conservada da proteína do nucleocapsídeo do virus da cinomose canina (rCDV NP) expressa em Escherichia coli empregando um gene sintético e codons otimizados. A expressão na cepa Star (média de $300 \mu \mathrm{g} / \mathrm{mL}$, purificada) foi confirmada por SDS-PAGE e Western blot utilizando anticorpos monoclonais anti-His-Tag. A antigenicidade da rCDVNP foi demonstrada por western blot e ELISA empregando soros de cães positivos e negativos. A rCDVNP foi inoculada em galinhas e imunoglobulina Y (gY) foi obtida e purificada a partir da gema. A produção média de IgY foi $28.55 \mathrm{mg} / \mathrm{mL}$. Anticorpos IgY reagiram com a proteína recombinante, quando analisados por Western blot e ELISA. Em resumo, nossos achados demonstram que a rCDVNP produzida é antigênica, uma vez que os anticorpos 
de soro de cães positivos para CDV reconheceram a proteína in vitro. Além disso, a rCDVNP foi imunogênica em galinhas, sendo possível isolar anticorpos IgY específicos a partir da gema do ovo em altas concentrações. Tomados em conjunto, estes resultados indicam que a rCDVNP juntamente com a IgY específica podem ser ferramentas úteis para elaborar ensaios de imunodiagnóstico de cinomose canina.

TERMOS DE INDEXAÇÃO: Cães, antigenia, imunogenia, proteína do nucleocapsídeo, cinomose canina, Escherichia coli, gene sintético, códon, expressão, CDV, NP, IgY, viroses.

\section{INTRODUCTION}

Canine distemper virus (CDV) causes a disease known as canine distemper (CD), characterized in acute systemic or chronic nervous infection (Beineke et al. 2009). CD is a worldwide problem and it is associated with high morbidity and mortality (Elia et al. 2015), being considered the second highest fatality rate of any infectious disease, after rabies, in domestic dogs around the world (Deem at al. 2000). In Brazil, previous studies have shown that CD is the most important cause of early death or euthanasia in dogs (Bentubo et al. 2007, Fighera et al. 2008). The disease affects various organs, resulting in respiratory, nervous and gastrointestinal disorders (Martella et al. 2008). It is also associated with severe leukopenia and immunosuppression, favoring opportunistic infections (Beineke et al. 2009).

CDV is a Morbillivirus and belongs to the family Paramyxoviridae (ICTV 2014). The genomic RNA of the CDV is single stranded, negative-sense, and encodes six structural proteins: fusion protein $(F)$, hemagglutinin $(H)$, matrix $(M)$, phosphoprotein $(P)$, viral polymerase protein (L) and the nucleocapsid protein (NP) (Elia et al. 2006). The NP has been separated in three regions, the variable $\mathrm{N}$-terminus, the variable $\mathrm{C}$-terminus and the highly conserved middle region (Yoshida et al. 1998). It is produced in abundant amounts by host cells (Stettler \& Zurbriggen 1995) being expressed early during the viral replication cycle (Latha et al. 2007b).

A variety of clinical parameters and immunodiagnostic assays can be performed for definitive ante mortem diagnosis of CD (Elia et al. 2015). However, due to the unpredictable and variable course of $\mathrm{CD}$, many times the final diagnosis is inconclusive (Frisk et al. 1999) or only based on the clinical manifestations of the dogs (Latha et al. 2007b). The recombinant DNA technology and its application facilitate routine diagnosis of infectious diseases (Balamurugan et al. 2010). Using the recombinant technology, some studies have demonstrated the detection of the NP or antibodies against NP for the CD diagnosis (Barben et al. 1999, Von Messling et al. 1999, Latha et al. 2007a, 2007b).

There are many options to express recombinant proteins depending on the specific requirement (Spencer et al. 2007), however, Escherichia coli expression dominates the expression systems and remains the first choice for laboratory investigations (Papaneophytou \& Kontopidis 2014). The expression in $E$. coli is relatively simple and a high yield of protein can be produced (LaVallie 2001). In order to further optimize protein expression, synthetic DNA have been frequently used providing an advantageous way to obtain genes encoding target proteins. Besides, it is possible to modify the natural gene with the aim of enhancing expression in heterologous hosts (Welch et al. 2009).

In this study, we demonstrated the expression of a conserved region of CDV NP in E. coli employing a codon optimized synthetic gene and the evaluation of its antigenic and immunogenic properties in vitro and in vivo.

\section{MATERIALS AND METHODS}

All experiments were conducted in accordance with protocols approved by the Comissão de Ética em Experimentação Animal (CEEA) of the Universidade Federal de Pelotas (Permit Number: 1251-2015).

\section{Production of recombinant CDV NP (rCDVNP)}

Construction of recombinant plasmid containing a codon optimized synthetic gene of CDV NP. All nucleotide sequences of the CDV nucleocapsid gene deposited in GenBank were analyzed and the conserved sequence located in the central region of NP gene was selected for this study (aa 222-316). The CDV NP nucleotide sequence was codon optimized for Escherichia coli expression and synthetized by GENONE ${ }^{\circledR}$. Geneious Pro 4.8 .5 and Vector NTI 8 softwares were used for analyses, edition, alignment and optimization of the sequence (Kearse et al. 2012, Lu \& Moriyama 2004). The synthetized gene was inserted into a pAE vector (Ramos et al. 2004) between restriction enzymes BamHI and HindIII resulting in the pAE-NP recombinant plasmid.

Cloning and expression of the rCDVNP. E. coli TOP10F strain was transformed with pAE-NP using the heat shock method according Froger \& Hall (2007). Screening of colonies by electrophoresis in $1 \%$ agarose gel was carried out in order to identify the pAE-NP. The recombinant clones were selected and amplified in LB medium (Kasvi ${ }^{\circledR}$, Brasil) with ampicillin $(100 \mu \mathrm{g} / \mathrm{mL})$. Thereafter, extraction of plasmid DNA by alkaline lysis with SDS was performed (Sambrook \& Russell 2006). Subsequently, E. coli Star strain was transformed with the recombinant pAE-NP (Froger \& Hall 2007) aiming protein expression. After, transformed cells were immersed into a tube containing LB medium (Kasvi $\left.{ }^{\circledR}\right)$ with ampicillin $(100 \mu \mathrm{g} / \mathrm{mL})$ and then the culture was incubated overnight at $37^{\circ} \mathrm{C}$ with agitation. The overnight culture was diluted 1:10 in LB medium (Kasvi ${ }^{\circledR}$ ) containing ampicillin $(100 \mu \mathrm{g} / \mathrm{mL})$ and incubated at $37^{\circ} \mathrm{C}$ until to attain the optical density $\left(\mathrm{OD}_{600}=0.6-0.8\right)$. The expression was induced with $0.5 \mathrm{mM}$ of Isopropyl $\beta$-D-1-thiogalactopyranoside (IPTG - Sigma USA) for 3 hours at $37^{\circ} \mathrm{C}$ with agitation for the production of rCDVNP.

Purification and analysis of the rCDVNP. The IPTG induced culture was centrifuged at $10,000 \mathrm{~g}$ for $10 \mathrm{~min}$ at $4^{\circ} \mathrm{C}$. The precipitate was suspended in buffer $\left(50 \mathrm{mM} \mathrm{NaH}_{2} \mathrm{PO}_{4}, 300 \mathrm{mM} \mathrm{NaCl}\right.$ and $20 \mathrm{mM}$ Imidazole) with lysozyme $(50 \mathrm{mg} / \mathrm{mL})$ and sonicated seven times for $20 \mathrm{~s}$ with $60 \mathrm{~Hz}$. The lysate was centrifuged at $10,000 \mathrm{~g}$ for $15 \mathrm{~min}$ at $4^{\circ} \mathrm{C}$ and then the precipitate was washed three times with phosphate buffered saline (PBS) ( $\mathrm{pH}$ 7.4). The precipitate was suspended in $0.2 \% \mathrm{~N}$-Lauroylsarcosine buffer $\left(50 \mathrm{mM} \mathrm{NaH}_{2} \mathrm{PO}_{4}, 300 \mathrm{mM} \mathrm{NaCl}\right.$, $20 \mathrm{mM}$ Imidazole and $0.2 \%(\mathrm{w} / \mathrm{v})$ of $\mathrm{N}$-Lauroylsarcosine) and remained 48 hours at $4^{\circ} \mathrm{C}$. After that, the solution was centrifuged at $10,000 \mathrm{~g}$ for $15 \mathrm{~min}$ at $4^{\circ} \mathrm{C}$ and then the supernatant was collected into a new tube. The recombinant protein was purified with $\mathrm{Ni}^{2+}$ affinity chromatography column (HisTrap ${ }^{\mathrm{TM}}$ FF, GE Healthcare ${ }^{\circledR}$ ). A step gradient of Imidazole was used to elute the bound proteins. Dialysis was carried out in PBS for 24 hours at $4^{\circ} \mathrm{C}$. The final yield of purified protein was estimated using $\mathrm{Qubit}^{\mathrm{TM}}$ fluorometric quantitation (Life Technologies ${ }^{\circledR}$ ).

Aliquots, obtained at each stage of rCDVNP expression and purification, were analyzed by $20 \%$ sodium dodecyl sulphate-polyacrylamide 
gel electrophoresis (SDS-PAGE) and Western blot. Proteins were transferred to $0.45 \mu \mathrm{m}$ nitrocellulose membrane $\left(\operatorname{BioRad}^{\circledR}\right)$ which was blocked overnight with $5 \%$ skimmed milk in phosphate buffered saline containing Tween 20 (PBS-T20). After five washes with PBS-T, the membrane was incubated with anti His-Tag monoclonal antibodies $\left(\right.$ Sigma $\left.{ }^{\circledR}, \mathrm{USA}\right)$ at $1: 10,000$ for $1 \mathrm{~h}$ at $37^{\circ} \mathrm{C}$. After removal the unbound antibodies, the membrane was incubated with rabbit anti-mouse IgG conjugated with HRPO (Sigma ${ }^{\circledR}$, USA) at $1: 5,000$ for $1 \mathrm{~h}$ at $37^{\circ} \mathrm{C}$. After five washing steps, 3,3',5,5'-tetramethylbenzidine (TMB) $\left(\right.$ Sigma $^{\circledR}$, USA) substrate was added for $5 \mathrm{~min}$ at room temperature.

\section{Antigenic evaluation of rCDVNP}

Serum samples. Blood samples were collected from the jugular vein via venopuncture from 10 dogs and kept at $-20^{\circ} \mathrm{C}$ until use. Five serum samples were collected from Bulldog young pups prior to vaccination and used as negative controls. The other five samples were collected from undefined breed dogs ( $>1$ year-old) after vaccination and used as positive controls. The positive or negative antibody status of all serum samples were confirmed by serum neutralization (data not shown).

Reactivity of the rCDVNP. In order to confirm the reactivity of the rCDVNP with polyclonal sera against CDV, Western blot was carried out under the same conditions previously described. Positive and negative dog sera were used as primary antibody at 1:20 dilution, overnight at $4^{\circ} \mathrm{C}$. Rabbit anti-dog IgG conjugated with HRPO (Sigma ${ }^{\circledR}$, USA) was used as secondary antibody at $1: 1,000$ for $1 \mathrm{~h}$ at $37^{\circ} \mathrm{C}$.

Antigenic properties of rCDVNP by Indirect ELISA. Optimal concentrations of rCDVNP, serum samples and conjugated antibodies dilution were obtained by checkboard titrations. Except as otherwise indicated, all incubation steps were performed at $37^{\circ} \mathrm{C}$. Three washings were performed with PBS-T20 between each step. Briefly, microtiter 96-well plates (Costar ${ }^{\circledR}$, USA) were coated with 100ng/well of rCDVNP in $0.05 \mathrm{M}$ carbonate buffer, $\mathrm{pH} 9.6$, at $4^{\circ} \mathrm{C}$ overnight. Nonspecific binding sites were blocked with $100 \mu \mathrm{L} /$ well of PBS-T with $5 \%$ skimmed milk for $1 \mathrm{~h}$. Serial dilutions (1:2,560-1:40) of dog serum samples were incubated for 2 hours $(100 \mu \mathrm{L} /$ well). Later, rabbit anti-dog IgG conjugated with HRPO (Sigma ${ }^{\circledR}$, USA) at 1:7,500 was incubated for $1 \mathrm{~h}(100 \mu \mathrm{L} /$ well). The reaction was visualized by using of o-phenylenediamine dihydrochloride (OPD) in phosphate citrate buffer (pH 5) containing $0.2 \%$ hydrogen peroxide $(50 \mu \mathrm{L} /$ well) as substrate after incubation for $15 \mathrm{~min}$ at room temperature. The reaction was stopped by adding $2.5 \mathrm{M} \mathrm{H}_{2} \mathrm{SO}_{4}$ and the absorbance was read at $492 \mathrm{~nm}$ by a microplate reader. Analyses were performed in triplicate.

\section{Immunogenic evaluation of rCDVNP}

Inoculation of rCDVNP in hens. Three laying hens New Hampshire Red 20-weeks-old were kept in individual cages with food and water ad libitum throughout the study. The inoculations were performed according Wen et al. (2012) with modifications. Briefly, 100 $\mu \mathrm{g}$ of rCDVNP diluted in PBS were emulsified with an equal volume of incomplete Freund's adjuvant (Sigma ${ }^{\circledR}$, USA) and inoculated in the pectoral muscles with a final volume of $1 \mathrm{~mL}$ distributed at two points. Animals were inoculated three times at intervals of two weeks. Eggs were collected and stored at $4^{\circ} \mathrm{C}$.

Purification of IgY. IgY was isolated according to the water solution method described by Akita \& Nakai (1992) with modifications. Briefly, the yolk was separated from the white and $5 \mathrm{~mL}$ of yolk were mixed with fresh and cold distilled water 9:1 (distilled water $\mathrm{pH}$ 5-5.5). This mixture was incubated for 6 hours at $4^{\circ} \mathrm{C}$ and centrifuged at $10,000 \mathrm{~g}$ for $25 \mathrm{~min}$ at $4^{\circ} \mathrm{C}$. The supernatant was collected through sterile gauzes. Three-step salt precipitation was performed to purify the IgY in the supernatant in turn. First, ammonium sulfate was added to $50 \%$ saturation, this solution was stirred at $4^{\circ} \mathrm{C}$ for $30 \mathrm{~min}$. Precipitate was collected by centrifugation at $10,000 \mathrm{~g}$ for $15 \mathrm{~min}$ at $4^{\circ} \mathrm{C}$ and dissolved to the original volume of yolk in PBS. Ammonium sulfate was added to $33 \%$ saturation and this solution was incubated $15 \mathrm{~min}$ and centrifuged as before. This step was repeated once and the precipitate was solubilized in $1 \mathrm{~mL}$ of PBS. Dialysis was carried out in PBS for 24 hours at $4^{\circ} \mathrm{C}$. Concentration of purified IgY was measured by Qubit ${ }^{\mathrm{TM}}$ fluorometric quantitation (Life Technologies ${ }^{\circledR}$ ). The polyclonal antibodies were stored at $-20^{\circ} \mathrm{C}$. The purification of IgY were analyzed by $15 \%$ SDS-PAGE.

Immunogenicity of rCDVNP. Western blot was carried out under the same conditions employed to confirm the presence of the rCDVNP. Representative samples of IgY isolated from egg yolks ( 0 and 7 weeks after first inoculation) were used as primary antibody at $1: 20$ overnight at $4^{\circ} \mathrm{C}$. Rabbit anti-chicken IgY conjugated with HRPO (Sigma ${ }^{\circledR}$, USA) was used as secondary antibody at $1: 5,000$ for 2 hours at $37^{\circ} \mathrm{C}$.

Evaluation of IgY anti-rCDVNP production by Indirect ELISA. Optimal concentrations of rCDVNP, IgY and conjugated antibodies were obtained by checkboard titration. The evaluation of IgY anti-rCDVNP production was carried out under the same conditions employed to evaluate the antigenic properties of the rCDVNP. Briefly, microtiter 96-well plate $\left(\right.$ Costar $^{\circledR}$, USA) were coated with 100ng/well of rCDVNP. IgY isolated from yolks at 0,4 , and 7 weeks after first inoculation were used as primary antibodies (1:50) and the secondary antibody used was rabbit anti-chicken IgY conjugated with HRPO (Sigma ${ }^{\circledR}$, USA) at 1:10,000. Analyses were performed in triplicate.

\section{RESULTS}

\section{Production of rCDVNP}

Recombinant plasmid pAE-NP. Two hundred and ninety-four base pairs (bp) corresponding to the middle nucleotide sequence of CDV NP were codon optimized, synthesized and directionally cloned into the plasmid pAE, generating the recombinant pAE-NP. Recombinant pAE-NP was successfully amplified in Escherichia coli TOP10F. This synthetized region resulted in a deduced amino acid sequence with 100\% homology with all others CDV NP deposited in GenBank.

Analysis of rCDVNP expression. The expression of the synthetic gene resulted in a protein of approximately $12 \mathrm{kDa}$, molecular weight as expected. Poly-histidine tag (6-His tag) was expressed fused to the recombinant protein, which facilitated its purification and it was used for the expression confirmation by anti His-Tag MAb (Fig.1). After purification, the protein yield was approximately $300 \mu \mathrm{g} / \mathrm{mL}$.

Antigenic evaluation of rCDVNP. In order to evaluate the antigenic properties of rCDVNP, Western blot and ELISA were performed. Antibodies from seropositive dogs recognized the rCDVNP by Western blot as shown in Figure 2, while no reactivity was observed with sera from the negative control. Reactivity was also observed in indirect ELISA using serial dilutions of positive control sera. Low absorbance values at all dilutions were detected with negative control (Fig.3).

\section{Immunogenic evaluation of rCDVNP}

Purification of IgY. The presence of IgY was confirmed by $15 \%$ SDS-PAGE which revealed two bands of approximately 68 and $27 \mathrm{kDa}$, respectively, corresponding to the heavy and 

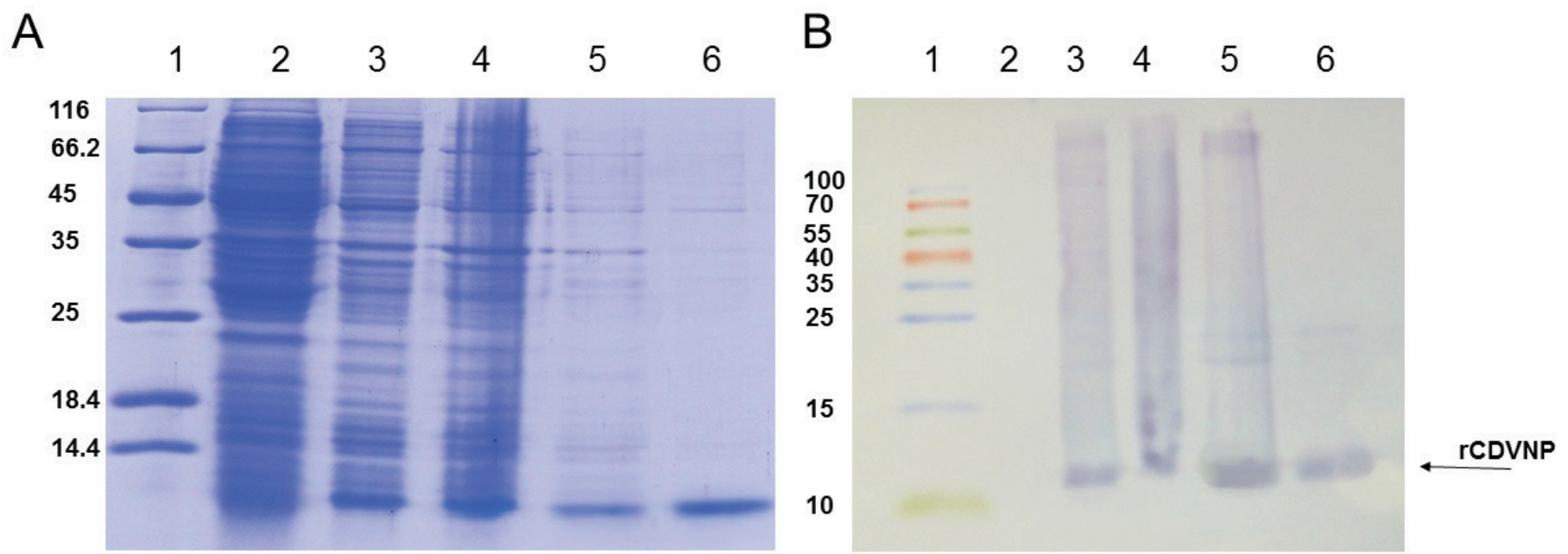

Fig.1. Analysis of rCDVNP expression. (A) 20\% SDS-PAGE: Lane 1 = Pierce $^{\mathrm{TM}}$ Unstained Protein MW Marker Thermo Scientific ${ }^{\mathrm{TM}}$, Lane $2=$ Escherichia coli star negative control, Lane $3=E$. coli star transformed with pAE-NP non induced, Lane $4=E$. coli star transformed with pAE-N induced, Lane $5=$ rCDVNP solubilized in $0.2 \%$ N-laurolylsarcosyne, Lane $6=$ purified rCDVNP. (B) Western blot: Lane $1=$ PageRuler $^{\mathrm{TM}}$ Prestained Protein Ladder Thermo Scientific ${ }^{\mathrm{TM}}$, Lane $2=$ E. coli star negative control, Lane $3=$ E. coli star transformed with pAE-NP non induced, Lane $4=E$. coli star transformed with pAE-N induced, Lane $5=$ rCDVNP solubilized in $0.2 \%$ N-laurolylsarcosyne, Lane 6 = purified rCDVNP (indicated by arrow).

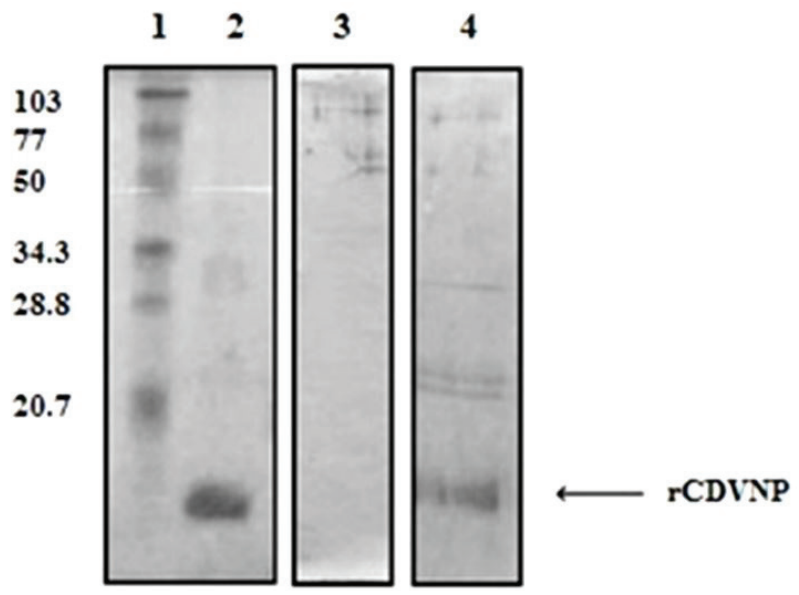

Fig.2. Reactivity of the rCDVNP with polyclonal serum against CDV. 20\% SDS-PAGE: Lane 1 = prestained SDS-PAGE Standards Bio-Rad $^{\circledR}$, Lane 2 = purified rCDVNP. Western blot: Lane $3=$ dog sera (negative control), Lane $4=$ dog sera (positive control) (rCDVNP is indicated by arrow).

light chains of IgY (data not show). The mean yield of IgY was $28.55 \mathrm{mg} / \mathrm{mL}$.

Immunogenic response to rCDVNP in hens. Inoculation of laying hens with rCDVNP resulted in a substantial production of specific IgY antibodies. The presence of specific IgY anti-rCDVNP in egg yolks were determined by Western blot analysis, in which a strong protein band of the molecular weight protein $(\sim 12 \mathrm{kDa})$ was identified. This band was detected in egg yolks of hens 7 weeks after the first inoculation, while remained undetectable in egg yolks derived from hens before the inoculations (Fig.4). In Figure 5, it is possible to visualize an increasing production of specific IgY anti rCDVNP after inoculations as assayed by indirect ELISA. These findings indicated that the recombinant CDV NP was highly immunogenic in hens.

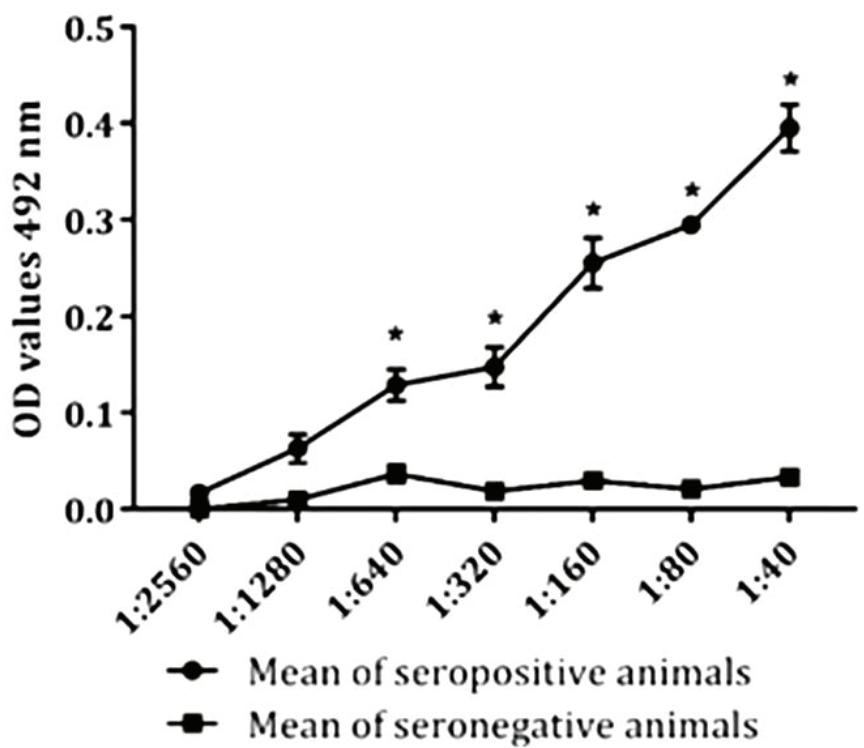

Fig.3. Antigenic properties of rCDVNP by indirect ELISA. Interaction of antigen-antibody has been evaluated by ELISA using serial dilutions of serum derived from five seropositive and five seronegative dogs against canine distemper. The lanes represent the means of the optical density (OD) values of the samples. All tests were performed in triplicate.

\section{DISCUSSION}

Recombinant protein expression technology has the potential to produce a reliable source of antigens for use in diagnostic assays (Spencer et al. 2007). Proteins of CDV, such as H protein (Chan et al. 2009, Cho et al. 2014) and NP (Barben et al. 1999, Latha et al. 2007a, 2007b, Von Messling et al. 1999), have been expressed to be used in immunodiagnostic tests. However, the $\mathrm{H}$ protein has shown antigenic alterations, since it is most likely to undergo changes under immunological 


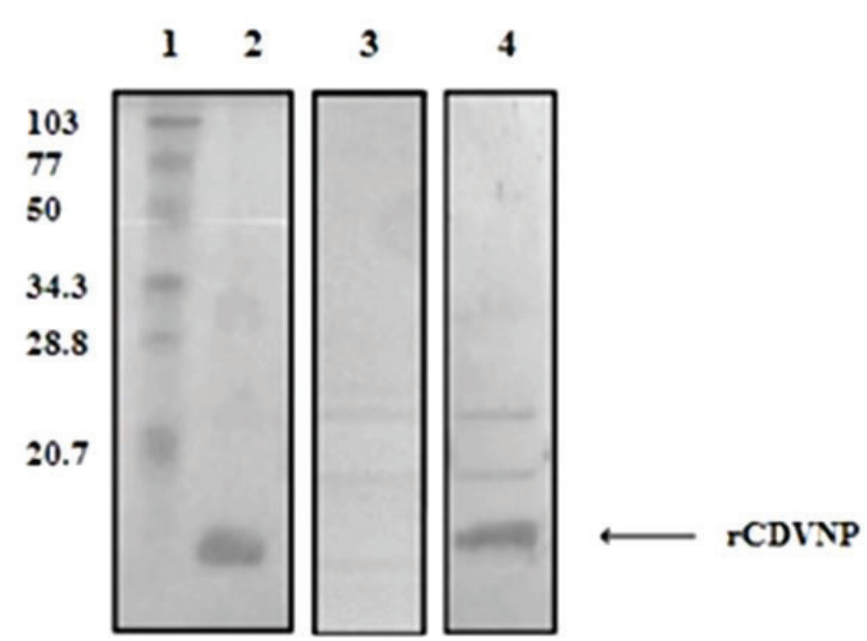

Fig.4. Immunogenicity of rCDVNP. 20\% SDS-PAGE: Lane 1 = Pre-stained SDS-PAGE Standards Bio-Rad ${ }^{\circledR}$, Lane 2 = purified rCDVNP. Western blot: Lane 3 = representative sample of IgY purified before the inoculations, Lane $4=$ representative sample of IgY purified 7 weeks after first inoculation (rCDVNP is indicated by arrow).

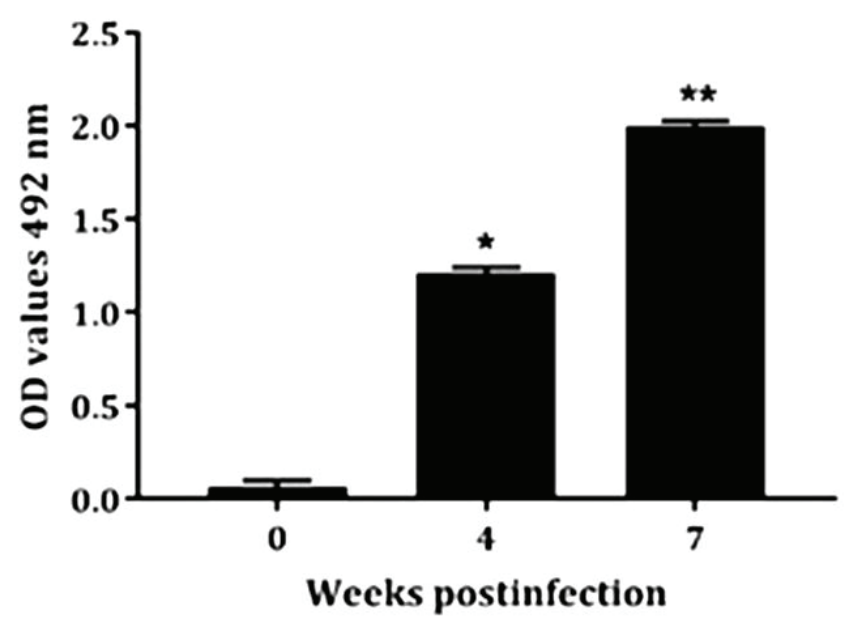

Fig.5. Evaluation of IgY anti-rCDVNP production by indirect ELISA. ELISA analysis of IgY anti-rCDVNP production with samples isolated at 0,4 and 7 weeks after the first inoculation.

pressure because it plays a role in the attachment of the virus to host cells (Shin et al. 1997b). NP is one of the most abundant proteins in CDV infections and the most conserved among morbilliviruses (Stettler \& Zurbriggen 1995). Due its characteristics, NP has been used as viral antigen for diagnosis tests of morbillivirus (Yadav et al. 2009) and also other viruses like influenza virus (Zhang et al. 2014), coronavirus (Chen et al. 2015) and bunyavirus (Lee et al. 2016).

In the present study, we cloned, expressed and purified a conserved region of CDV NP (amino acids \# 222-316) from a synthetic and codon optimized gene for Escherichia coli expression. Recombinant CDV NP has already been expressed in different systems such as baculovirus (Von Messling et al. 1999) and VERO cells (Shin et al. 1997a). The CDV NP expressed either in baculovirus or mammalian cell expression systems were found to be contaminated with cellular or baculovirus proteins resulting in nonspecific reactions (Shin et al. 1997a, Von Messling et al. 1999). In this study, the rCDVNP was expressed in E. coli and the resulting protein was purified successfully.

It has been reported that the production of recombinant proteins in bacteria is simple and more economical when compared to other systems (Yadav et al. 2009). Despite the E. coli lack of ability to make post-translational modifications in the expressed protein (Spencer et al. 2007), in this study it seemed do not interfere with the antigen specificity. Using codon optimization for E. coli, CDV NP was expressed from a synthetic gene, thus reducing time and costs when compared to the expression using the native gene (Newcomb et al. 2007). Other studies have also expressed CDV NP efficiently in E. coli, but using the native gene cloned from virus isolated from the studied region (Barben et al. 1999, Latha et al. 2007b, Yi \& Cheng 2014).

The rCDVNP demonstrated to be antigenic, since CD positive dog sera recognized the protein both in its native and denatured form, without showing nonspecific reactions. In ELISA, antibodies from seropositive dogs recognized rCDVNP even at higher dilutions (Fig.3). A similar study evaluating the antigenicity of the CDV NP expressed in E. coli was demonstrated by Barben et al. (1999) and Latha et al. (2007a, 2007b), in which epitopes of CDV NP also were recognized by antibodies present in dogs by Western blot, ELISA and dot-blot assays. $\mathrm{NP}$ can be the protein of choice to be used for research of the serological status of recent infections because it is the protein that induces higher antibodies titer in Morbillivirus infections (Elia et al. 2015, Von Messling et al. 1999).

The use of IgY to detect viral NP in immunodiagnostics assays is an efficient approach, described in studies with other viruses (Kammila et al. 2008, Veerasami et al. 2008). Although the production of IgY against the whole particle of CDV has already been demonstrated (Schmidt et al. 1989, Guimarães et al. 2009), the methodology described in our work shows some improvements when compared to the study performed by Schmidt et al. (1989), as we detected the presence of specific IgY in a shorter period of time. However, the amount of specific IgY obtained in these studies cannot be compared, since the techniques employed in the experiments were not the same. In addition, it is well established that the use of recombinant proteins to immunize animals is safer, faster and more specific when compared to native viral antigens (Spencer et al. 2007). Notably, our results demonstrated that the rCDVNP expressed in E. coli was highly immunogenic in hens and it was possible to obtain high concentrations of specific IgY antibodies from the egg yolk. This methodology represents a promising tool for the production of specific polyclonal antibodies since yolk antibodies are an alternative to mammalian antibodies and desirable from the perspective of animal welfare (Karlsson et al. 2004). Besides, it is economically viable, because the production of IgY is relatively fast and of high yield (Polson et al. 1980), as observed in this study mainly after the second inoculation in hens.

Further studies need to be performed in order to evaluate the reagents here produced as tools for diagnostic. However, our findings indicated that both rCDVNP and specific anti-CDV antibodies might be useful for several immunodiagnostic assays. Recombinant proteins have been used in indirect ELISAs either for monitoring levels of antibodies or detection 
of recent infections (Von Messling et al. 1999). As well, specific anti-CDV IgY can be used to confirm the presence of the antigen by direct ELISA (Vasconcellos et al. 2010, Zhang et al. 2016), for fast detection of the viral antigen by immunochromatographic tests (Zhang et al. 2016), and also to confirm the presence of the virus in tissues, as the main antibody in immunochemistry (Schmidt et al. 1989).

\section{CONCLUSIONS}

In summary, the synthetic gene encoding a conserved region of the nucleocapsid protein of canine distemper virus (rCDV NP) was successfully cloned and expressed in Escherichia coli resulting in a recombinant NP protein highly antigenic and immunogenic.

Moreover, our results indicated that this approach may be a practical strategy for the large-scale production of specific anti-CDV antibodies to be used in diagnostic tests of CDV.

Conflict of interest statement.- The authors have no competing interests.

Acknowledgements.- Financial support was provided by Coordenação de Aperfeiçoamento de Pessoal de Nível Superior (CAPES), Fundação de Amparo a Pesquisa do Estado do Rio Grande do Sul (FAPERGS) and Conselho Nacional de Desenvolvimento Científico e Tecnológico (CNPq).

\section{REFERENCES}

Akita E.M. \& Nakai S. 1992. Immunoglobulins from egg yolk: Isolation and purification. J. Food Sci. 57(3):629-634. <http://dx.doi.org/10.1111/j.1365-2621.1992. tb08058.x>

Balamurugan V., Venkatesan G., Sen A., Annamalai L., Bhanuprakash V. \& Singh R.K. 2010. Recombinant protein-based viral disease diagnostics in veterinary medicine. Expert Rev. Mol. Diagn. 10(6):731-753. <http:// dx.doi.org/10.1586/erm.10.61 < <PMid:20843198>

Barben G., Stettler M., Jaggy A., Vandevelde M. \& Zurbriggen A. 1999. Detection of IgM antibodies against a recombinant nucleocapsid protein of canine distemper virus in dog sera using a dot-blot assay. J. Vet. Med. A 46(2):115-122.<http://dx.doi.org/10.1046/j.1439-0442.1999.00198. $\mathrm{x}><$ PMid:10216448>

Beineke A., Puff C., Seehusen F. \& Baumgärtner W. 2009. Pathogenesis and immunopathology of systemic and nervous canine distemper. Vet. Immunol. Immunop. 127(1/2):1-18. <http://dx.doi.org/10.1016/j. vetimm.2008.09.023><PMid:19019458>

Bentubo H.D.L., Tomaz M.A., Bondan E.F. \& Lallo M.A. 2007. Expectativa de vida e causas de morte em cães na área metropolitana de São Paulo (Brasil). Ciência Rural 37(4):1021-1026. <http://dx.doi.org/10.1590/ S0103-84782007000400016>

Chan K., Hsieh H., Wang H., Lee Y., Sung M., Wong M. \& Hsu W. 2009. Identification, expression and antigenic analysis of recombinant hemagglutinin proteins of canine distemper virus. J. Virol. Methods 155(1):18-24.<http://dx.doi. org/10.1016/j.jviromet.2008.09.024><PMid:18951919>

Chen Y., Chan K.H., Kang Y., Chen H., Luk H.K., Poon R.W., Chan J.F., Yuen K.Y., Xia N., Lau S.K. \& Woo P.C. 2015. A sensitive and specific antigen detection assay for Middle East respiratory syndrome coronavirus. Emerg. Microbes Infect. 4(4):e26. <http://dx.doi.org/10.1038/emi.2015.26><PMid:26421268>

Cho K., Kim J., Yoo H., Kim D., Park S., Song C., Choi I. \& Lee J. 2014. Use of hydrophilic extra-viral domain of canine distemper virus $\mathrm{H}$ protein for enzyme-linked immunosorbent assay development. J. Vet. Sci. 15(4):503509. <http://dx.doi.org/10.4142/jvs.2014.15.4.503><PMid:25234325>

Deem S.L., Spelman L.H., Yates R.A. \& Montali R.J. 2000. Canine distemper in terrestrial carnivores: a review. J. Zoo Wildl. Med. 31(4):441-451.
<http://dx.doi.org/10.1638/1042-7260(2000)031[0441:CDITCA]2.0. C0;2> <PMid:11428391>

Elia G., Decaro N., Martella V., Cirone F., Lucente M.S., Lorusso E., Di Trani L. \& Buonavoglia C. 2006. Detection of canine distemper virus in dogs by real-time RT-PCR. J. Virol. Methods 136(1/2):171-176. <http://dx.doi. org/10.1016/j.jviromet.2006.05.004><PMid:16750863>

Elia G., Camero M., Losurdo M., Lucente M.S., Larocca V., Martella V., Decaro N. \& Buonavoglia C. 2015. Virological and serological findings in dogs with naturally occurring distemper. J. Virol. Methods 213:127-130. <http:// dx.doi.org/10.1016/j.jviromet.2014.12.004><PMid:25512131>

Fighera R.A., Souza T.M., Silva M.C., Brum J.C., Graça D.G., Kommers G.D., Irigoyen L.F. \& Barros C.S.L. 2008. Causas de morte e razões para eutanásia de cães da Mesorregião do Centro Ocidental Rio-Grandense (1965-2004). Pesq. Vet. Bras. 28(4):223-230. <http://dx.doi.org/10.1590/S0100736X2008000400005>

Frisk A.L., König M., Moritz A. \& Baumgärtner W. 1999. Detection of canine distemper virus nucleoprotein RNA by reverse transcription-PCR using serum, whole blood, and cerebrospinal fluid from dogs with distemper. J. Clin. Microbiol. 37(11):3634-3643. <PMid:10523566>

Froger A. \& Hall J.E. 2007. Transformation of plasmid DNA into E. coli using the heat shock method. JoVE (6):253. <PMid:18997900>

Guimarães M.C.C., Amaral L.G., Borges F.V., Vieira H.P.L., Matta C.G.F. \& Matta M.F.R. 2009. Characterization of an IgY polyclonal antibodies directed against the canine distemper virus. Revta Ciênc. Méd. Biol. 8(1):18-25.

ICTV 2014. International Committee on Taxonomy of Viruses. Available at <http://www.ictvonline.org/virusTaxonomy.asp> Access on Dec. 15, 2016.

Kammila S., Das D., Bhatnagar P.K., Sunwoo H.H., Zayas-Zamora G., King M. \& Suresh M.R. 2008. A rapid point of care immunoswab assay for SARS-CoV detection. J. Virol. Methods 152(1/2):77-84.<http://dx.doi.org/10.1016/j. jviromet.2008.05.023><PMid:18620761>

Karlsson M., Kollberg H. \& Larsson A.. 2004. Chicken IgY: utilizing the evolutionary advantage. World Poultry Sci. J. 60(3):341-348. <http:// dx.doi.org/10.1079/WPS200422>

Kearse M., Moir R., Wilson A., Stones-Havas S., Cheung M., Sturrock S., Buxton S., Cooper A., Markowitz S., Duran C., Thierer T., Ashton B., Meintjes P. \& Drummond A. 2012. Geneious basic: an integrated and extendable desktop software platform for the organization and analysis of sequence data. Bioinformatics 28(12):1647-1649. <http://dx.doi.org/10.1093/ bioinformatics/bts199><PMid:22543367>

Latha D., Geetha M., Ramadass P. \& Narayanan R.B. 2007a. Development of recombinant nucleocapsid protein based IgM-ELISA for the early detection of distemper infection in dogs. Vet. Immunol. Immunop. 119(3/4):278-286. <http://dx.doi.org/10.1016/j.vetimm.2007.06.006> <PMid:17659785>

Latha D., Geetha M., Ramadass P. \& Narayanan R.B. 2007b. Evalution of ELISA based on the conserved and functional middle region of nucleocapsid protein to detect distemper infection in dogs. Vet. Microbiol. 120(3/4):251-260. <http://dx.doi.org/10.1016/j.vetmic.2006.11.019><PMid:17224247>

LaVallie E.R. 2001. Production of recombinant proteins in Escherichia coli. Curr. Protoc. Protein Sci. Chapter 5:1. <http://dx.doi.org/10.1002/0471140864. ps0501s00 > <PMid:18429175>

Lee H., Kim E.J., Song J.Y., Choi J.S., Lee J.Y., Cho I.S. \& Shin Y.K. 2016. 2015Development and evaluation of a competitive enzyme-linked immunosorbent assay using a monoclonal antibody for diagnosis of severe fever with thrombocytopenia syndrome virus in bovine sera. J. Vet. Sci. 17(3):307-314. <http://dx.doi.org/10.4142/jvs.2016.17.3.307> <PMid:26435543>

Lu G. \& Moriyama E.N. 2004. Vector NTI, a balanced all-in-one sequence analysis suite. Brief. Bioinform. 5(4):378-388. <http://dx.doi.org/10.1093/ bib/5.4.378><PMid:15606974> 
Martella V., Elia G. \& Buonavoglia C. 2008. Canine distemper virus. Vet. Clin. N. Am., Small Anim. Pract. 38(4):787-797. <http://dx.doi.org/10.1016/j. cvsm.2008.02.007><PMid:18501278>

Newcomb J., Carlson R. \& Aldrich S.C. 2007. Genome Synthesis and Design Futures: Implications for the US Economy. Bio Economic Research Associates, Cambridge, MA. Available at <http://www.bio-era.net/reports/ genome.html>.

Papaneophytou C.P. \& Kontopidis G. 2014. Statistical approaches to maximize recombinant protein expression in Escherichia coli: a general review. Protein Expr. Purif. 94:22-32. <http://dx.doi.org/10.1016/j.pep.2013.10.016> $<$ PMid:24211770>

Polson A., Von Wechmar M.B. \& Van Regenmortel M.H. 1980. Isolation of viral IgY antibodies from yolks of immunized hens. Immunol. Commun. 9(5):475-493. <http://dx.doi.org/10.3109/08820138009066010> $<$ PMid:7429529>

Ramos C.R.R., Abreu P.A.E., Nascimento A.L.T.O. \& Ho P.L. 2004. A high copy T7 Escherichia coli expression vector for the production of recombinant proteins with a minimal N-terminal His-tagged fusion peptide. Braz. J. Med. Biol. Res. 37(8):1103-1109. <http://dx.doi.org/10.1590/S0100879X2004000800001><PMid:15273812>

Sambrook J. \& Russell D.W. 2006. Preparation of Plasmid DNA by Alkaline Lysis with SDS: minipreparation. Cold Spring Harbor Protocols. 2006(1). <http://dx.doi.org/10.1101/pdb.prot4084><PMid:22485489>

Schmidt P., Hafner A., Reubel G.H., Wanke R., Franke V., Lösch U. \& Dahme E. 1989. Production of antibodies to canine distemper virus in chicken eggs for immunohistochemistry. J. Vet. Med. B 36(1/10):661-668. <http://dx.doi. org/10.1111/j.1439-0450.1989.tb00659.x><PMid:2609804>

Shin Y., Mori T., Tomonaga K., Iwatsuki K., Kai C. \& Mikami T. 1997a. Expression of the nucleocapsid protein gene of the canine distemper virus. J. Vet. Med. Sci. 59(1):51-53.<http://dx.doi.org/10.1292/jvms.59.51><PMid:9035079>

Shin Y.S., Miyashita N., Hirayama N., Gemma T., Mikami T., Mori T., Iwatsuki K., Kai C. \& Yoshida E. 1997b. Molecular and phylogenetic analyses of the haemagglutinin $(\mathrm{H})$ proteins of field isolates of canine distemper virus from naturally infected dogs. J. Gen. Virol. 78(2):373-380. <http://dx.doi. org/10.1099/0022-1317-78-2-373><PMid:9018060>

Spencer K., Osorio F.A. \& Hiscox J.A. 2007. Recombinant viral proteins for use in diagnostic ELISAs to detect virus infection. Vaccine 25(30):5653-5659. <http://dx.doi.org/10.1016/j.vaccine.2007.02.053> <PMid:17478017>

Stettler M. \& Zurbriggen A. 1995. Nucleotide and deduced amino acid sequences of the nucleocapsid protein of the virulent A75/17-CDV strain of canine distemper virus. Vet. Microbiol. 44(2/4):211-217.<http://dx.doi. org/10.1016/0378-1135(95)00014-2><PMid:8588315>
Vasconcellos F.A., Coutinho M.L., da Silva E.F., Fernandes C.P., Monte L.G., Seyffert N., Dellagostin O.A. \& Aleixo J.A. 2010. Testing different antigen capture ELISA formats for detection of Leptospira spp. in human blood serum. Trans. R. Soc. Trop. Med. Hyg. 104(4):259-264. <http://dx.doi. org/10.1016/j.trstmh.2009.10.005><PMid:19942245>

Veerasami M., Singanallur N.B., Thirumeni N., Rana S.K., Shanmugham R., Ponsekaran S., Muthukrishnan M. \& Villuppanoor S.A. 2008. Serotyping of foot-and-mouth disease virus by antigen capture-ELISA using monoclonal antibodies and chicken IgY. New Microbiol. 31(4):549-554.<PMid:19123312>

Von Messling V., Harder T.C., Moennig V., Rautenberg P., Nolte I. \& Haas L. 1999. Rapid and sensitive detection of Immunoglobulin M (IgM) and IgG antibodies against canine distemper virus by a new recombinant nucleocapsid protein-based enzyme-linked immunosorbent assay. J. Clin. Microbiol. 37(4):1049-1056. <PMid:10074525>

Welch M., Govindarajan S., Ness J.E., Villalobos A., Gurney A., Minshull J. \& Gustafsson C. 2009. Design parameters to control synthetic gene expression in Escherichia coli. Plos One 4(9):e7002. <http://dx.doi.org/10.1371/ journal.pone.0007002><PMid:19759823>

Wen J., Zhao S., He D., Yang Y., Li Y. \& Zhu S. 2012. Preparation and characterization of egg yolk immunoglobulin Y specific to influenza B virus. Antiviral Res. 93(1):154-159. <http://dx.doi.org/10.1016/j.antiviral.2011.11.005> <PMid:22127067>

Yadav V., Balamurugan V., Bhanuprakash V., Sen A., Bhanot V., Venkatesan G., Riyesh T. \& Singh R.K. 2009. Expression of peste des petits ruminants virus nucleocapsid protein in prokaryotic system and its potential use as a diagnostic antigen or immunogen. J. Virol. Methods 162(1/2):56-63. <http://dx.doi.org/10.1016/j.jviromet.2009.07.014><PMid:19646481>

Yi L. \& Cheng S. 2014. A monoclonal antibody against truncated N protein (aa 277-471) of canine distemper virus. Monoclon. Antib. Immunodiagn. Immunother. 33(1):52-56. <http://dx.doi.org/10.1089/mab.2013.0066> $<$ PMid:24555938>

Yoshida E., Iwatsuki K., Miyashita N., Gemma T., Kai C. \& Mikami T. 1998. Molecular analysis of the nucleocapsid protein of recent isolates of canine distemper virus in Japan. Vet. Microbiol. 59(2/3):237-244. <http://dx.doi. org/10.1016/S0378-1135(97)00194-6><PMid:9549863>

Zhang R.H., Li C.H., He W.X., Wang C.L., Xu T., Jin M.L. \& Chen H.C. 2014. Development of latex agglutination test with nucleoprotein as antigen for detection of antibodies to swine influenza virus. Int. Immunopharmacol. 19(2):201-205. <http://dx.doi.org/10.1016/j.intimp.2014.01.026> $<$ PMid:24508548>

Zhang X., Diraviyam T., Li X., Yao G. \& Michael A. 2016. Preparation of chicken IgY against recombinant E2 protein of bovine viral diarrhea virus (BVDV) and development of ELISA and ICA for BVDV detection. Biosci. Biotechnol. Biochem. 80(12):2467-2472.<http://dx.doi.org/10.1080/09168451.20 16.1217144><PMid:27484991> 